\title{
JOB SATISFACTION OF OCCUPATIONAL PHYSICIANS IN COMMERCIAL AND OTHER DELIVERY SETTINGS: A COMPARATIVE AND EXPLORATIVE STUDY
}

\author{
HARMEN NICO PLOMP and ALLARD J. VAN DER BEEK \\ VU University Medical Centre, The EMGO Institute for Health and Care Research, Amsterdam, the Netherlands \\ Department of Public and Occupational Health
}

\begin{abstract}
Objectives: Commercialization of occupational health services (OHS) and transition to a supplier market which started in 1995, has affected work and working conditions of occupational physicians (OPs) profoundly. OPs have lost influence on the organization of their work and managers took over control. This study explores the impact of commercialization on job satisfaction of occupational physicians. Material and Methods: Data were collected through a questionnaire completed by 797 OPs, members of the Netherlands Association of Occupational Medicine (response: 45\%). A range of work satisfiers and dissatisfiers measures was included that, according to the Social Action Approach, could explain the variation in job satisfaction. Stepwise multivariate regression analyses were performed to explore to what extent the differences in job satisfaction can be attributed to the characteristics of the setting, biographical variables, satisfiers and dissatisfiers. Results: Occupational physicians in commercial settings had the lowest average score as regards job satisfaction (6.7) contrasting sharply with their colleagues in private practices (8.7) and in non-commercial settings (7.9). The variation in job satisfaction between delivery settings could largely be attributed to satisfiers and dissatisfiers. Biographical characteristics (age, gender) had no effect. The data suggested that not commercialization as such, but the ability of commercial OHS providers to integrate professional values was the crucial factor to bring about job satisfaction. Conclusions: The challenge for commercial OHS providers is to preserve the professional zeal in OPs by integrating professional values in their organization in order to improve the quality of the services and the attractiveness of the profession.
\end{abstract}

Key words:

Job satisfaction, Commercialization, Occupational health services, Occupational physician, Delivery setting

\section{INTRODUCTION}

The wellbeing of physicians is not only of importance for themselves, but also for their patients and the healthcare institute where they are employed. It influences patient satisfaction, the turnover among physicians, the morale among healthcare workers, the frequency of mistakes made and, therefore, also the quality of the care provided [1-3]. Despite this, research into job satisfaction remains fragmentary, with various indicators present, rendering comparisons difficult. Furthermore, the findings of research into job satisfaction among physicians are not unambiguous and vary per context, specialization and geographical region.

In general, satisfaction among physicians appears to have remained reasonably stable over the years and its most important determinants have been found to be job demand, job control, collegial support and income [4,5]. However, significant differences between physicians

Received: October 21, 2013. Accepted: May 2, 2014.

Corresponding author: H.N. Plomp, Department of Public and Occupational Health, VU University Medical Centre, Van der Boechorststraat 7, NL-1081 BT Amsterdam, the Netherlands (e-mail: hn.plomp@vumc.nl). 
(specializations) and geographical regions have been reported [6,7]. Janus et al. found that job satisfaction among American physicians was higher than that of their German colleagues [6,7]. For both countries, "being involved with the decision-making concerning work" was an important predictor for satisfaction. Numerous studies have revealed decreasing job satisfaction in physicians as a result of managed care arrangements that limit the possibilities for referrals, autonomy and prescribing medicines [8]. Another cause is related to the difficulties encountered by physicians in dealing with more self-assured patients who are highly educated and behave like consumers; in general an erosion of public trust in physicians has taken hold. Obviously, dissatisfaction and satisfaction are not equally distributed and dependent on work environment, expectations of colleagues, patients and healthcare managers. Mechanic talks of 'boutique practices,' referring to the institutes where strikingly high levels of job satisfaction have been observed [8].

Findings from Australia reveal an alarmingly high rate of almost $50 \%$ of physicians reporting high stress scores [9]. Under the title "Unhappy doctors, what are the causes and what can be done?" the British Medical Journal has reported on two seminars for physicians and healthcare managers in the USA and UK on the topics of job satisfaction and changes in healthcare systems [10]. The most important cause is considered to be the more traditional pattern of expectations of physicians that is not in line with the expectations that the society (employers, governments, and patients) has of physicians with respect to accountability and patient-centeredness.

As far as we know, very little is known about job satisfaction of occupational physicians (OPs). A Dutch study indicates that stress among OPs does not differ from the average levels of all Dutch physicians, but OPs in commercial occupational health services (OHS) display burnout symptoms significantly more frequently in comparison with their colleagues in other delivery settings [11].

\section{OBJECTIVES}

The study on job satisfaction and work experiences among OPs in the Netherlands was triggered by the system shift that has taken place in the field of occupational health and safety since 1994 when a series of new regulations was implemented. First of all, OHS were made obligatory for all employers, but at the same time the ban on profit-making was lifted and competition among OHS centers was promoted. This implied a boost of the market for OHS. New commercial OHS centers that operate on the national level started competing with the traditional medium size OHS that used to have a monopolistic position in their region.

Currently, commercial OHS have become the most common delivery setting for occupational health in the Netherlands covering about $75 \%$ of the commercial market, with the 3 largest national OHS centers employing about $60 \%$ of all occupational physicians [12]. This regime change has profoundly affected the work content and working conditions of OPs, and has had enormous consequences for the culture and organization of occupational healthcare and the position of OPs in this arena [13]. It can be characterized as a transition from a supplier market in which OPs determine the content and goal of the services, towards a customer market where the employers determine which services they purchase and at what price.

The supplier market, where the influence of OPs is high, is idealistic in nature, primarily geared towards prevention and promotion of healthy employees. In the customer market, however, cost-effectiveness and customer-orientation are the dominant values, and financing takes place through 'fee for services' as opposed to the 'capitation system' based on the solidarity principle, which was characteristic for the supplier market. In the commercial OHS, OPs are hardly represented at the management level and they are not involved in the contracting with companies. The work processes that OPs are expected to focus on have 
been largely standardized and are driven by business process norms.

Due to the discontent with working conditions in the commercial OHS providers and as a consequence of changes in the Work Environment Act in 2005, the number of private occupational health practices has grown rapidly by $15-20 \%$ of all OPs. About $10 \%$ of OPs are still working in non-commercial settings, mainly employed by large companies in the so-called company OHS. Their work setting resembles most the non-commercial OHS environment from prior to 1994; they do not work with a 'fee for service' system, but on the basis of a budget. They are much more tightly integrated into the company. In addition, they have geared their services specifically to the company's needs and are not confronted with financial targets.

The aim of the present study is to explore the impact of commercialization on the work and wellbeing of OPs. The primary objectives are:

- to compare job satisfaction and work satisfiers and dissatisfiers for commercial and other delivery settings,

- to explore to what extent the differences in job satisfaction can be explained by characteristics of the delivery setting, biographical variables, and experienced work satisfiers and dissatisfiers.

\section{MATERIAL AND METHODS}

\section{Sample and data collection}

Data were collected through a questionnaire sent by email (the NetQ program) to all members of the Netherlands Association of OPs (NVAB; $N=1786$ ). The membership file was made available by the board and only used for this study. After two reminders, 797 valid completed questionnaires were returned (response rate 45\%). With the exception of those who had their own motives for not participating in the study, reasons for non-response were: incorrect email address $(\mathrm{N}=98)$, incompletely filled questionnaire
$(\mathrm{N}=60)$, and problems with digital questionnaires. Representativeness was estimated by comparing the gender and age distribution in the research group with the NVAB membership file: the percentage of women was almost identical in both groups $(34.8 \%$ in the research group and $33.8 \%$ on the membership file), but the physicians in the age group between 50 and 59 years were overrepresented in the research group (51.3\% as opposed to $42.4 \%$ in the membership file). However, age turned out to have no effect on job satisfaction. According to the regulations of the Ethical Committee of the VU-University Medical Centre, no informed consent was required for this study since no patients were involved.

\section{Conceptualizing and measuring Job satisfaction and its determinants}

For conceptualizing and measuring the concept 'job satisfaction' and its determinants, we used the 'Social Action Approach' developed by the British industrial sociologists Goldthrope and others [14] during the sixties of the last century and elaborated by Kalleberg [15]. They reacted against social scientists who view a variation in job satisfaction solely as a function of the job characteristics and argued that satisfaction cannot be explained without the knowledge of the meaning people put to their work activities.

Job satisfaction was defined as "an overall affective orientation on the part of individuals toward work roles which they are presently occupying" and perceived as a unitary concept, measured in this study with one question ("How content are you with your current work situation?"). It was expressed with the use of a 1-10 VAS score.

However, the causation of job satisfaction is considered to be multidimensional and to be a function of the evaluation of various aspects of work. It is assumed that people attach different values to various work aspects (intrinsic referring to content and prospects, extrinsic referring to material reward, social aspects and autonomy) and that the values 
or ideas about 'good work' (what is desirable with respect to work) explain a large part of the variation of job satisfaction. These values or ideas can originate from personal preferences, needs, talent, education, life experiences, expectations, etc. Physicians and other professionals, however, usually have outspoken values and ideas about 'good practice' that are taught during the life-long educational and socializing processes and reinforced through intercollegiate discourses.

In this study, work values or desired work experiences were asked for 11 work aspects (derived from the list used in the Goldthrope studies) and summed up in Table 1 by using the question "Please indicate how important these aspects are for you in your work" (range: $1=$ not important at all, $5=$ highly important). The results are presented in Table 2, section B.

The actual work experience was evaluated for the same 11 aspects using the question "To what extent are these aspects present in your current job?" (range: 1 - completely absent, 5 - fully present). They are called "job rewards" by Kalleberg and constitute potential sources for job satisfaction. The outcomes are presented in section A of Table 2.
The difference between the desired and actual work experience indicates someone's satisfaction with a work aspect, which was called a satisfier. The results are shown in section $\mathrm{C}$ of Table 2.

Finally, dissatisfaction was evaluated using 11 items, as summed up in Table 3, that were derived from the Herzberg's motivation-hygiene theory [16] and translated to a situation of (Dutch) OPs.

\section{Analysis}

In Tables 1-3, job satisfaction and the various indicators of work satisfiers and dissatisfiers were calculated and compared for each delivery setting. Furthermore, job satisfaction was used as the dependent variable in a series of stepwise multivariate linear regression analyses.

In the 1st step of all analyses, the different settings were entered as independent dummy variables into the model by default, i.e., "company OHS," "private OHS practice" and "other" were compared to "commercial OHS." In the 2nd step, the regression model was expanded by entering three biographical variables (i.e., gender, year of birth, and years in current position). In the 3rd step, the regression model was further

Table 1. Aspects of work used in the calculation of actual and desired work experience

\begin{tabular}{lcc}
\hline \multicolumn{1}{c}{ Aspect* } & \multicolumn{1}{c}{$\begin{array}{c}\text { Dimension } \\
\text { Cronbach } \\
\alpha\end{array}$} \\
\hline $\begin{array}{l}\text { 1. The opportunity to develop professional expertise } \\
\text { 2. Interesting and challenging work }\end{array}$ & intrinsic (composed index) \\
3. Large autonomy in the work & autonomy (composed index) \\
4. Taking one's own responsibility & \\
5. Good atmosphere in the working unit & social (composed index) \\
6. Good relationship with colleagues & \\
7. Good financial reward & extrinsic \\
8. Reward by merit & \\
9. Job security & & 0.84 \\
10. Self-contracting companies & economic independency \\
11. Organizing one's own work & \\
\hline
\end{tabular}

* In the questionnaire, OPs evaluated their actual and desired work experience as regards 11 aspects. Aspects 1-6 were compressed into indices if Cronbach $\alpha$ equaled $>0.60$ (measure for reliability of a scale). For aspects 7-11, representing the dimension "extrinsic" and "economic independency," this criterion was not met. Therefore, in statistical analyses, not the indices/dimensions were used in the statistical analysis, but the separate aspects. ns - not statistically significant. 
Table 2. Satisfiers, the actual and desired work experience for various work aspects per delivery setting (mean scores)

\begin{tabular}{|c|c|c|c|c|c|c|c|c|}
\hline $\begin{array}{c}\text { Delivery } \\
\text { setting }\end{array}$ & Intrinsic & Autonomy & Social & $\begin{array}{c}\text { Financial } \\
\text { reward }\end{array}$ & $\begin{array}{l}\text { Reward } \\
\text { by merit }\end{array}$ & $\begin{array}{c}\text { Self- } \\
\text { contracting }\end{array}$ & $\begin{array}{c}\text { Organizing } \\
\text { one's own } \\
\text { work }\end{array}$ & $\begin{array}{c}\text { Job } \\
\text { security }\end{array}$ \\
\hline \multicolumn{9}{|c|}{ A) Actual work experience* } \\
\hline commercial OHS & 3.7 & 4.1 & 3.9 & 3.5 & 2.1 & 2.0 & 3.5 & 3.9 \\
\hline in-company OHS & 4.4 & 4.6 & 4.4 & 4.2 & 3.0 & 2.3 & 3.6 & 4.2 \\
\hline private practice & 4.5 & 4.9 & 4.1 & 4.6 & 4.3 & 4.4 & 4.5 & 2.5 \\
\hline other & 4.3 & 4.4 & 4.1 & 3.7 & 2.3 & 2.2 & 3.9 & 4.1 \\
\hline total & 4.0 & 4.3 & 4.0 & 3.8 & 2.5 & 2.5 & 3.7 & 3.7 \\
\hline p Chi ${ }^{2}$ & 0.00 & 0.00 & 0.00 & 0.00 & 0.00 & 0.00 & 0.00 & 0.00 \\
\hline \multicolumn{9}{|c|}{ B) Desired work experience** } \\
\hline commercial OHS & 4.3 & 4.3 & 4.1 & 3.7 & 2.9 & 2.2 & 3.5 & 3.6 \\
\hline in-company OHS & 4.4 & 4.4 & 4.1 & 3.7 & 3.0 & 3.3 & 3.3 & 3.6 \\
\hline private practice & 4.3 & 4.6 & 3.8 & 3.9 & 3.6 & 3.6 & 4.0 & 1.9 \\
\hline other & 4.5 & 4.4 & 4.1 & 3.5 & 3.1 & 2.3 & 3.7 & 3.2 \\
\hline total & 4.3 & 4.4 & 4.1 & 3.7 & 3.1 & 2.4 & 3.6 & 3.3 \\
\hline $\mathrm{p} \mathrm{Chi}{ }^{2}$ & 0.42 & 0.06 & 0.15 & 0.04 & 0.00 & 0.00 & 0.00 & 0.00 \\
\hline \multicolumn{9}{|l|}{ C) Satisfiers $* * *$} \\
\hline commercial OHS & -0.6 & -0.2 & -0.2 & -0.2 & -0.9 & -0.2 & 0.0 & 0.3 \\
\hline in-company OHS & 0.0 & 0.2 & 0.3 & 0.5 & 0.1 & 0.0 & 0.3 & 0.6 \\
\hline private practice & 0.2 & 0.3 & 0.3 & 0.7 & 0.6 & 0.8 & 0.5 & 0.7 \\
\hline other & -0.2 & 0.0 & 0.0 & 0.2 & -0.8 & -0.2 & 0.3 & 0.9 \\
\hline total & -0.4 & -0.1 & -0.1 & 0.1 & -0.5 & 0.0 & 0.1 & 0.4 \\
\hline p Chi ${ }^{2}$ & 0.00 & 0.00 & 0.00 & 0.00 & 0.00 & 0.00 & 0.00 & 0.00 \\
\hline
\end{tabular}

* Scale from 1 (absent) to 5 (fully present).

** Scale from 1 (unimportant) to 5 (highly important).

*** The difference between the desired and the actual work experience. Scale from -1 (not satisfied) to +1 (satisfied and more).

OHS - occupational health services.

Table 3. Dissatisfiers per delivery setting (averages on a scale of 1-5)

\begin{tabular}{|c|c|c|c|c|c|}
\hline Variable & $\begin{array}{c}\text { Commercial } \\
\text { OHS } \\
(\mathrm{N}=528)\end{array}$ & $\begin{array}{c}\text { In-company } \\
\text { OHS } \\
(\mathrm{N}=72)\end{array}$ & $\begin{array}{c}\text { Private } \\
\text { OHS practice } \\
(\mathrm{N}=137)\end{array}$ & $\begin{array}{c}\text { Other } \\
(\mathrm{N}=59)\end{array}$ & $\begin{array}{c}\text { Total } \\
(\mathrm{N}=796)\end{array}$ \\
\hline \multicolumn{6}{|l|}{ Work pressure } \\
\hline A) time pressure & 3.8 & 3.7 & 3.1 & 3.8 & $3.6^{*}$ \\
\hline B) administrative burden & 4.0 & 3.3 & 3.0 & 3.6 & $3.7^{*}$ \\
\hline \multicolumn{6}{|l|}{ Security } \\
\hline C) job insecurity & 2.9 & 2.5 & 2.0 & 2.1 & $2.7^{*}$ \\
\hline
\end{tabular}


Table 3. Dissatisfiers per delivery setting (averages on a scale of 1-5) - cont.

\begin{tabular}{|c|c|c|c|c|c|}
\hline Variable & $\begin{array}{c}\text { Commercial } \\
\text { OHS } \\
(\mathrm{N}=528)\end{array}$ & $\begin{array}{c}\text { In-company } \\
\text { OHS } \\
(\mathrm{N}=72)\end{array}$ & $\begin{array}{c}\text { Private } \\
\text { OHS practice } \\
(\mathrm{N}=137)\end{array}$ & $\begin{array}{c}\text { Other } \\
(\mathrm{N}=59)\end{array}$ & $\begin{array}{c}\text { Total } \\
(\mathrm{N}=796)\end{array}$ \\
\hline \multicolumn{6}{|l|}{ Integrity } \\
\hline D) following the professional guidelines not feasible & 2.9 & 2.7 & 2.7 & 2.6 & $2.9^{*}$ \\
\hline F) professional standards difficult to maintain & 2.6 & 1.7 & 2.0 & 2.2 & $2.4^{*}$ \\
\hline G) independent advise impossible & 2.2 & 1.8 & 1.7 & 1.9 & $2.0^{*}$ \\
\hline \multicolumn{6}{|l|}{ Profession } \\
\hline $\begin{array}{l}\text { H) previously the conditions for being a good OP were } \\
\text { better }\end{array}$ & 2.9 & 2.4 & 1.9 & 2.5 & $2.7^{*}$ \\
\hline $\begin{array}{l}\text { I) commercializing has a negative impact on the professional } \\
\text { performance }\end{array}$ & 3.9 & 3.5 & 3.0 & 3.9 & $3.7^{*}$ \\
\hline J) preference for work outside $\mathrm{OH}$ field & 2.9 & 2.6 & 2.8 & 2.8 & 2.8 \\
\hline K) cannot recommend the OP profession to others & 3.6 & 3.2 & 3.1 & 3.4 & $3.5^{*}$ \\
\hline $\begin{array}{l}\text { E) my knowledge and competences cannot be realized } \\
\text { in my current work }\end{array}$ & 2.7 & 2.3 & 2.1 & 2.5 & $2.5^{*}$ \\
\hline
\end{tabular}

OHS - occupational health services; $\mathrm{OH}$ - occupational health; OP - occupational physician.

* $\mathrm{p} \mathrm{Chi}^{2}<0.00$.

Table 4. Job satisfaction explained by delivery setting, biography, satisfiers and dissatisfiers in a stepwise multiple regression with job satisfaction as a dependent variable

\begin{tabular}{|c|c|c|c|c|c|c|c|c|}
\hline \multirow[b]{2}{*}{ Variable } & \multicolumn{2}{|c|}{ Step 1} & \multicolumn{2}{|c|}{ Step 2} & \multicolumn{2}{|c|}{ Step 3} & \multicolumn{2}{|c|}{ Step 4} \\
\hline & $\begin{array}{l}\text { stand. } \\
\beta\end{array}$ & $\mathrm{p}$ & $\begin{array}{c}\text { stand. } \\
\beta\end{array}$ & $\mathrm{p}$ & $\begin{array}{c}\text { stand. } \\
\beta\end{array}$ & $\mathrm{p}$ & $\begin{array}{c}\text { stand. } \\
\beta\end{array}$ & $\mathrm{p}$ \\
\hline \multicolumn{9}{|l|}{ Delivery setting } \\
\hline in-company OHS vs. commercial OHS & 0.222 & 0.00 & 0.219 & 0.00 & 0.107 & 0.00 & 0.058 & 0.02 \\
\hline private $\mathrm{OHS}$ practice vs. commercial OHS & 0.449 & 0.00 & 0.445 & 0.00 & 0.241 & 0.00 & 0.145 & 0.00 \\
\hline other vs. commercial OHS & 0.163 & 0.00 & 0.160 & 0.00 & 0.110 & 0.00 & 0.072 & 0.00 \\
\hline \multicolumn{9}{|l|}{ Biography } \\
\hline gender & & & 0.017 & 0.64 & 0.026 & 0.40 & 0.046 & 0.09 \\
\hline year of birth & & & -0.009 & 0.78 & 0.004 & 0.88 & -0.034 & 0.19 \\
\hline seniority in the current position (years) & & & -0.046 & 0.20 & -0.038 & 0.21 & -0.029 & 0.28 \\
\hline \multicolumn{9}{|l|}{$\begin{array}{l}\text { Satisfiers (the difference between the desired and } \\
\text { the actual work experience) }\end{array}$} \\
\hline intrinsic & & & & & 0.180 & 0.00 & 0.083 & 0.00 \\
\hline autonomy & & & & & 0.123 & 0.00 & 0.069 & 0.01 \\
\hline social & & & & & 0.232 & 0.00 & 0.156 & 0.00 \\
\hline good financial reward & & & & & 0.067 & 0.03 & 0.050 & 0.07 \\
\hline
\end{tabular}


Table 4. Job satisfaction explained by delivery setting, biography, satisfiers and dissatisfiers in a stepwise multiple regression with job satisfaction as a dependent variable - cont.

\begin{tabular}{|c|c|c|c|c|c|c|c|c|}
\hline \multirow[b]{2}{*}{ Variable } & \multicolumn{2}{|c|}{ Step 1} & \multicolumn{2}{|c|}{ Step 2} & \multicolumn{2}{|c|}{ Step 3} & \multicolumn{2}{|c|}{ Step 4} \\
\hline & $\begin{array}{c}\text { stand. } \\
\beta\end{array}$ & $\mathrm{p}$ & $\begin{array}{c}\text { stand. } \\
\beta\end{array}$ & $\mathrm{p}$ & $\begin{array}{c}\text { stand. } \\
\beta\end{array}$ & $\mathrm{p}$ & $\begin{array}{c}\text { stand. } \\
\beta\end{array}$ & $\mathrm{p}$ \\
\hline reward after merit & & & & & 0.092 & 0.00 & 0.077 & 0.00 \\
\hline job security & & & & & 0.081 & 0.00 & -0.026 & 0.31 \\
\hline self-contracting companies & & & & & -0.019 & 0.52 & -0.027 & 0.31 \\
\hline organizing one's own work & & & & & 0.074 & 0.01 & 0.033 & 0.20 \\
\hline \multicolumn{9}{|l|}{ Dissatisfiers (workload) } \\
\hline \multicolumn{9}{|l|}{ working pressure } \\
\hline A) time pressure & & & & & & & -0.032 & 0.21 \\
\hline \multicolumn{8}{|l|}{ security } & 0.00 \\
\hline C) job insecurity & & & & & & & -0.140 & 0.00 \\
\hline \multicolumn{9}{|l|}{ integrity } \\
\hline $\begin{array}{l}\text { D) following the professional guidelines not } \\
\text { feasible }\end{array}$ & & & & & & & -0.018 & 0.49 \\
\hline F) professional standards difficult to maintain & & & & & & & -0.086 & 0.00 \\
\hline G) independent advise impossible & & & & & & & -0.083 & 0.00 \\
\hline \multicolumn{9}{|l|}{ profession } \\
\hline $\begin{array}{l}\text { H) previously the conditions for being a good OP } \\
\text { were better }\end{array}$ & & & & & & & -0.065 & 0.03 \\
\hline $\begin{array}{l}\text { I) commercializing has a negative impact on the } \\
\text { professional performance }\end{array}$ & & & & & & & -0.048 & 0.07 \\
\hline J) preference for work outside $\mathrm{OH}$ field & & & & & & & -0.062 & 0.01 \\
\hline $\begin{array}{l}\text { K) cannot recommend the OP profession to } \\
\text { others }\end{array}$ & & & & & & & -0.080 & 0.00 \\
\hline $\begin{array}{l}\text { E) my knowledge and competences cannot be } \\
\text { realized in my current work }\end{array}$ & & & & & & & -0.129 & 0.00 \\
\hline $\mathrm{R}^{2}$ & 0.22 & & 0.23 & & & & & \\
\hline $\mathrm{p}$ & 0.00 & & 0.62 & & & & & \\
\hline
\end{tabular}

$\mathrm{R}^{2}$ - explained variance; $\beta$ - regression coefficient.

extended by entering 8 indicators of work satisfiers as additional independent variables. In the 4th step, 11 indicators of work dissatisfiers were also entered into the regression model. For all 4 regression models, the explained variance $\left(\mathrm{R}^{2}\right)$ was determined as well as the significance of change obtained from inclusion of additional independent variables as presented in Table 4. Also, the standardized betas and corresponding $\mathrm{p}$ values of all independent variables were retrieved. The differences were accepted as statistically significant at $\mathrm{p}<0.05$. 


\section{RESULTS}

Table 5 presents the distribution of respondents over the different delivery settings. There were only small differences with respect to age and BIG-registration (a state declaration of professional competence). The percentage of women and part-timers is higher among those that work for commercial OHS providers. On average, the respondents have been working in their current work setting for 10 years except for the OPs in private practices, who have, on average, worked 5 years (since 2005) in their current work situation.

\section{Univariate outcomes}

With a score of 8.5, OPs in private practices reported the highest job satisfaction, while their colleagues in commercial delivery settings had the lowest score with an average score of 6.7 ; but there were considerable differences indicated by the standard deviation; the highest score of a single commercial OHS provider was 7.5 and the lowest 5.6. Also the "actual work experience" score in the various work dimensions shows comparable differences between work settings (Table 2, section A). OPs in private practices had the highest scores in all dimensions, especially in the "autonomy" dimension, with the exception of the "social" and "job security" dimensions. OPs in commercial OHS had low scores in these dimensions, even in the "social" dimension, which had a relatively high desirability score in this setting.

The differences between the settings were much smaller for "desired work experience" (Table 2, section B) and even not significant for the main work aspects (intrinsic, autonomy and social ones). This means that OPs in the different delivery settings were almost fully in agreement regarding what constitutes 'good work.' The highest scores in all settings were in the dimensions of "autonomy" and "intrinsic." OPs in private practices put "freedom in planning working hours" in the third place, while OPs in the other settings gave higher priority to "social" and "job security" dimensions. "Good financial rewards" took fourth place for all OPs.

Table 2, section $\mathrm{C}$, shows that OPs in private practices had the highest satisfiers (a difference between the desired and the actual work experience) concerning all work aspects. This was opposite for OPs in commercial settings: they scored lowest for all satisfiers, with the exception of "job security." The majority of these OPs were not happy with the intrinsic dimension, while almost $45 \%$ felt the same way about the "social" dimension.

Table 5. Biographical characteristics and job satisfaction per delivery setting

\begin{tabular}{|c|c|c|c|c|c|c|}
\hline Variable & $\begin{array}{l}\text { Commercial } \\
\text { OHS } \\
(\mathrm{N}=528)\end{array}$ & $\begin{array}{l}\text { In-company } \\
\text { OHS } \\
(\mathrm{N}=72)\end{array}$ & $\begin{array}{l}\text { Private OHS } \\
\text { practice } \\
(\mathrm{N}=137)\end{array}$ & $\begin{array}{l}\text { Other* } \\
(\mathrm{N}=59)\end{array}$ & $\begin{array}{c}\text { Total } \\
(\mathrm{N}=796)\end{array}$ & $\begin{array}{c}\mathrm{p} \\
\mathrm{Chi}^{2}\end{array}$ \\
\hline Gender - men $(\%)$ & 62.5 & 73.6 & 71.5 & 69.5 & 65.6 & 0.08 \\
\hline Age (years) & 51.0 & 51.0 & 51.0 & 53.0 & 51.0 & 0.12 \\
\hline Seniority in current position (years) & 12.8 & 10.9 & 5.5 & 11.1 & 11.2 & 0.00 \\
\hline Working time (\% full time) & 51.3 & 68.1 & 65.7 & 62.7 & 56.2 & 0.00 \\
\hline $\begin{array}{l}\text { BIG-registered (a State declaration of } \\
\text { professional competence) }\end{array}$ & 92.9 & 88.9 & 96.4 & 93.2 & 93.2 & 0.03 \\
\hline $\begin{array}{l}\text { Job satisfaction (average VAS-score range: } \\
1=\text { very discontented; } 10=\text { completely } \\
\text { content) } \pm \text { SD }\end{array}$ & $6.7 \pm 1.5$ & $7.9 \pm 1.1$ & $8.5 \pm 0.9$ & $7.6 \pm 1.3$ & $7.2 \pm 1.5$ & 0.00 \\
\hline
\end{tabular}

BIG - Beroepen Individuele Gezondheidszorg; VAS -Visual Analogue Scale; SD - standard deviation; OHS - Occupational Health Services.

* The category "Other" comprises occupational physicians working in curative care, research departments, or in a combination of work settings. 
As regards the dissatisfiers, OPs from all settings showed less divergence (Table 3), although those in commercial settings had systematically higher dissatisfaction scores. The highest dissatisfiers score was reported for working pressure (A, B), with "The poor image of the profession" $(\mathrm{J}, \mathrm{K}, \mathrm{I})$ taking second place, and "Threatening integrity in professional practice" (D and F) in the last one. Evidently, for many respondents, in all work situations, the feeling persisted that the commercialization of their profession had rendered them unable to carry out their work in compliance with the professional norms.

\section{Multivariate outcome}

Finally, stepwise multivariate regression analyses showed that the included satisfiers and dissatisfiers explained a considerable part of the variation in job satisfaction between the different delivery settings, as is shown by the strong decrease in the standardized $\beta$ of delivery settings in steps 3 and 4 in Table 4. Biographical variables (gender, age, years worked in the current position), on the other hand, had no effect on the general job satisfaction. In the 4th step, the satisfiers "organizing one's own work," "self-contracting companies," and "job security" turned out to be no longer statistically significant.

The social dimension is the most important contributing satisfier, followed by intrinsic, reward by merit and autonomy. "Job insecurity" $(\mathrm{C})$ turns out to be the dissatisfier that undermines general job satisfaction the most, followed by the "lack of professional challenge" (E), "administrative burden" (B), "threatening of professional standards" (F) and "independency" (G). The dissatisfiers "following guidelines not feasible" (D), "time pressure" (A) and "the negative judgment on commercializing" (I) became non-significant in comparison with other independent variables. The beta in the 4th step for delivery setting indicated that some of the differences between the commercial setting and other settings remained unexplained.
More information was required to explain these setting differences, especially between the commercial OHS and the private $\mathrm{OHS}$ practices.

\section{DISCUSSION}

Overall, OPs in commercial settings felt deprived; they judged their work least positively (6.7) and scored the lowest in nearly all satisfiers, and the highest in all dissatisfiers. In contrast, OPs in private practices reported the highest job satisfaction (8.5) and obtained the highest scores in all satisfiers, with the exception of the "social" and "job security." Physicians in non-commercial OHS, in the curative health care sector or in research ("Other") took the middle position. The variations in job satisfaction in different delivery settings could largely be explained by satisfiers and dissatisfiers included in the study. Satisfiers that most strongly contributed to general job satisfaction were autonomy, intrinsic and social work aspects, and for physicians in private practices - "organizing one's own work" and "good financial reward." Dissatisfiers that detracted most from job satisfaction were: "job insecurity" (C), "lack of professional challenge" (E), "administrative burden" (B), "threatened professional integrity" (F, G), and "poor public image of the profession" (J, K).

Occupational physicians within commercial OHS evaluated their work and working conditions more often as unattractive and more stressful in several areas, but commercialization as such cannot be regarded as the cause of all this dissatisfaction. In the multiple regression analyses, the negative judgment on commercializing of OHS disappeared when the satisfiers and dissatisfiers were added to the model. Moreover, the average job satisfaction scores of the individual commercial OHS providers in this study diverged considerably (5.6-7.5), which highlights that some commercial OHS centers are apparently much more able to create the conditions for a positive work experience for OPs than other. This underlines the importance 
of integrating professional values and aspirations in the operational management.

The outcomes of the present study are in line with the results of studies on the impact of management involvement on job satisfaction in physicians; traditional core values, such as autonomy and control over their own practice, have been found to correlate strongly with job satisfaction of the professionals [17]. The discontent with managed care arrangements, however, appeared to be a strong incentive to redesign these arrangements in order to cope with the grievances and needs of both the professionals and clients [18,19].

The results of this cross-sectional study were affected by the social-economic constellation of that moment, which was rather unfavorable for commercial OHS due to the shrinking market. This might at least partly explain the strong emphasis on economic outcomes and neglecting professional interests. Another restriction is the method of data collection, the structured questionnaire, which produces only a global picture and gives no information on motives and intentions in specific situations. Only qualitative research in the work-setting can provide a more complete and realistic insight into satisfiers and dissatisfiers of occupational physicians and into clues for improvements.

\section{CONCLUSIONS}

Commercialization and the transition to a supplier market have created a more dynamic field and a greater diversity in OHS supply under the management of businessoriented managers, but it ultimately resulted in lower job satisfaction of OPs. The influence and involvement of OPs, however, have too often become marginalized and professional values and ambitions have been under pressure. Particularly in a commercial setting, clarity about the professional integrity and independence is vital for the credibility and quality of the service and, therefore, professional arrangements need shelters to enable them to organize their profession and to protect them against too powerful stakeholders [20].

Hence, the great challenge for OHS providers is to develop structures and practices that make clear how professional integrity and values can be preserved in a commercial environment in order to maintain and improve the quality of the services and the attractiveness of the profession.

\section{REFERENCES}

1. Landon BE, Reschovsky J, Blumenthal D. Changes in career satisfaction among primary care and specialist physicians, 1997-2001. JAMA. 2003;289(4):442-9, http://dx.doi. org/10.1001/jama.289.4.442.

2. Landon BE, Reschovsky JD, Pham HH, Blumenthal D. Leaving medicine: The consequences of physician dissatisfaction. Med Care. 2006;44(3):234-42, http://dx.doi.org/10.1097/01. mlr.0000199848.17133.9b.

3. Wallace JE, Lemaire JB, Ghali WA. Physician wellness: A missing quality indicator. Lancet. 2009;374(9702):1714-21, http://dx.doi.org/10.1016/S0140-6736(09)61424-0.

4. Scheurer D, Mc Kean S, Miller J, Wetterneck T. U.S. physicians satisfaction: A systematic review. J Hosp Med. 2009; 4(9):560-8, http://dx.doi.org/10.1002/jhm.496.

5. Schmit Jongbloed LJ, Borleffs JC, van Lohuizen MT, CohenSchotanus J. [Job satisfaction among physicians during their career]. Ned Tijdschr Geneeskd. 2010;154(22):A1691. Dutch.

6. Murray A, Montgomery JE, Chang H, Rogers WH, Inui T, Safran DG. Doctor discontent. A comparison of physician satisfaction in different delivery system settings, 1986 and 1997. J Gen Intern Med. 2001;16(7):452-9, http://dx.doi. org/10.1046/j.1525-1497.2001.016007452.x.

7. Janus K, Amelung VE, Baker LC, Gaitanides M, SchwartzFW, Rundall TG. Job satisfaction and motivation among physicians in academic medical centers: Insights from a cross-national study. J Health Polit Policy Law. 2008;33(6):1133-67, http://dx.doi.org/10.1215/03616878-2008-035. 
8. Mechanic D. Physician discontent: Challenges and opportunities. JAMA. 2003;290(7):941-6, http://dx.doi.org/10.1001/ jama.290.7.941.

9. Chew M, Williams A. Australian general practitioners: Desperately seeking satisfaction. Med J Aust. 2001;175(2):85-6.

10. Edwards N, Kornacki MJ, Silversin J. Unhappy doctors: What are the causes and what can be done? BMJ. 2002;324(7341): 835-8, http://dx.doi.org/10.1136/bmj.324.7341.835.

11. Stommen NCJ, Attekum van A, Kant IJ. [The occupational physician as entrepreneur, a passion or burden?]. TBV. 2010;15(4):149-55. Dutch.

12. van der Sluis E, Stolper K. [Occupational Health Services, future is now, a realistic vision on the market of work-related care]. Utrecht: IG\&H, Consultance; 2011. Dutch.

13. Plomp HN. The impact of the introduction of market incentives on occupational health services and occupational health professionals: Experiences from The Netherlands. Health Policy. 2008;88(1):25-37, http://dx.doi.org/10.1016/ j.healthpol.2008.02.003.

14. Goldthrorpe JK, Lockwood D, Bechhofer F, Platt J. The affluent worker: Industrial attitudes and behavior. Cambridge: Cambridge University Press; 1968.
15. Kalleberg Arne L. Work values and job rewards: A theory of job satisfaction. Am Sociol Rev. 1977;42(1):124-43, http://dx.doi.org/10.2307/2117735.

16. Herzberg F. Motivation-hygiene profiles, pinpointing what ails the organization. Organizational Dynamic. 2003;3(2): 18-29, http://dx.doi.org/10.1016/0090-2616(74)90007-2.

17. Stoddart JJ, Hargraves JL, Reed M, Vratil A. Managed care, professional autonomy and income: Effects on physician career satisfaction. J Gen Intern Med.2001;16(10):675-84,http://dx.doi.org/10.1111/j.15251497.2001.01206.x.

18. Mechanic D. Managed care and the imperative for a new professional ethic. Health Aff (Millwood). 2000;19(5): 100-11, http://dx.doi.org/10.1377/hlthaff.19.5.100.

19. Mechanic D. Physician discontent: Challenges and opportunities. JAMA. 2003;290(7):941-6, http://dx.doi.org/10.1001/ jama.290.7.941.

20. Freidson E. Occupational autonomy and labor market shelters. In professionalism reborn, theory, prophecy and policy. Cambridge UK: Polity Press; 1994. p. 75-91.

This work is available in Open Access model and licensed under a Creative Commons Attribution-NonCommercial 3.0 Poland License - http://creativecommons.org/ licenses/by-nc/3.0/pl/deed.en. 